\title{
PEMBELAJARAN KELILING BANGUN DATAR MENURUT STANDAR NATIONAL COUNCIL OF TEACHERS OF MATHEMATICS (NCTM) DENGAN SETTING KOOPERATIF PADA SISWA KELAS 3 SD MUHAMMADIYAH 9 MALANG
}

\author{
Dyah Worowirastri Ekowati \\ e-mail:dyah_umm@yahoo.com
}

\begin{abstract}
The purpose of this research is produce the material circumference of plane according to standart National Council Of Teachers Mathematics (NCTM) with cooperative setting. To get the purpose of this research used qualitatif research of action class. The study circumference of plane according to standart National Council Of Teachers Mathematics (NCTM) with cooperative setting in this research do with developed of 4 components NCTM, there are assignment, discourse, environment and analysis. The steps of this study are identification of the problem, design of act, collect data, and analysis data which all do in two cycles. Based on the result of study, it is ascertainable the average of score the result of study had been around increase. At the average of score in post-test first cycle as big as 71.72 and then the average of score in post-test second cycle had been around increase become 85.68. Beside that it is ascertainable, the completeness result of study in first and second cycle had been around increase, as big as $72,41 \%$ the students get score $\geq 65$ in first cycle and increase becomes $96.55 \%$ in second cycle, this case is getting better of the success of criteria is $80 \%$. Whereas in average score process of the study increases, at first cycle as big as $94.55 \%$ increase at second cycle becomes $98.87 \%$.
\end{abstract}

\begin{abstract}
Abstrak: Penelitian ini bertujuan untuk menghasilkan pembelajaran keliling bangun datar menurut standar National Council Of Teachers Of Mathematics (NCTM) dengan setting kooperatif. Untuk mencapai tujuan penelitian tersebut digunakan penelitian kualitatif jenis penelitian tindakan kelas. Pembelajaran keliling bangun datar menurut standar National Council Of Teachers Of Mathematics (NCTM) dengan setting kooperatif dalam penelitian ini dilakukan dengan mengembangkan 4 komponen NCTM yaitu tugas, wacana, lingkungan dan tugas. Adapun langkah-langkah pembelajarannya adalah identifikasi masalah, perancangan tindakan, pengumpulan data, serta analisis data yang semuanya dilaksanakan di dalam dua siklus. Berdasarkan hasil tes pembelajaran, diketahui rata-rata nilai tes hasil belajar siswa mengalami peningkatan. Pada rata-rata nilai pada tes akhir siklus 1 sebesar 71.72, dan kemudian rata-rata nilai pada tes akhir siklus II mengalami peningkatan menjadi 85.68. Selain itu diketahui pula, bahwa ketuntasan hasil belajar pada siklus I dan II mengalami peningkatan, sebanyak $72,41 \%$ siswa telah mencapai skor $\geq 65$ pada siklus I dan meningkat menjadi $96.55 \%$ pada siklus II, hal ini melebihi kriteria keberhasilan yaitu $80 \%$. Pada rata-rata nilai proses pembelajaran mengalami peningkatan, pada siklus I sebesar $94.55 \%$ meningkat pada siklus II menjadi $98.87 \%$.
\end{abstract}

Kata Kunci: pembelajaran keliling bangun datar, standar National Council Of Teachers Of Mathematics (NCTM), setting kooperatif

Tujuan belajar geometri menurut Freudental adalah untuk memahami tentang ruang, membantu siswa menghadirkan perasaan mengagumi terciptanya alam semesta, siswa-siswa harus belajar untuk tahu, meng- eksplorasi,agar bisa hidup, bernafas dan bergerak lebih baik. Mendukung pendapat tersebut, Kennedy \& Tipps (1994:387) menyatakan bahwa dengan pembelajaran geometri siswa mampu mengembangkan ke 
kemampuan pemecahan masalah dan mendukung banyak topik lain dalam matematitika.

Dengan belajar geometri siswa dapat mengembangkan imajinasi dari khayalan menjadi berpikir logis sehingga siswa memiliki keterampilan salah satunya yaitu merancang suatu bangun datar maupun ruang. Dalam mengembangkan keterampilan siswa untuk merangcang bangun-bangun tersebut, siswa harus memahami tentang konsep panjang, lebar, keliling, maupun luas. Pemahaman tentang konsep-konsep tersebut bermanfaat dalam kehidupan sehari-hari maupun untuk pengembangan lebih lanjut. Namun kenyataannya, banyak siswa yang masih mengalami kesulitan dalam memahami konsep-konsep yang diungkapkan di atas. Seperti yang terjadi di SD Muhammadiyah 9 Malang, yaitu sekolah tempat penulis pernah mengajar pada tahun 2006 yang lalu.

Berdasarkan hasil pengamatan dan wawancara dengan guru kelas III SD $\mathrm{Mu}-$ hammadiyah 9 pada awal januari 2010, diketahui bahwa siswa merasakan kesulitan memahami dan menerapkan materi keliling bangun datar yang merupakan subbagian dari geometri. Selain itu juga diketahui, banyak siswa keliru dalam memaknai definisi keliling melalui gambar. Hal ini dapat dimengerti karena pembelajaran keliling bangun datar di SD ini cenderung berorientasi pada guru dan pelaksanaannya juga cenderung dilaksanakan secara klasikal, sehingga kurang menumbuhkembangkan kemampuan berpikir siswa.

Berdasarkan hasil pengamatan juga diketahui bahwa penggunaan media dan alat peraga sangat jarang dilakukan oleh guru. Walaupun hal tersebut dilakukan, porsinya sangat sedikit dan biasanya guru yang memperagakan di depan kelas sedangkan siswa memperhatikan dari tempat duduknya masing-masing. Kemudian dilanjutkan guru dengan memberikan contoh-contoh dan latihan-latihan. Sementara siswa hanya mendengar, memperhatikan, mencatat, dan me- ngerjakan latihan-latihan yang diberikan oleh guru. Meskipun dalam menyelesaikan latihan tersebut ada beberapa siswa yang dapat menggunakan aturan-aturan yang telah diberikan, namun hal itu bersifat sementara. Siswa akan cepat lupa pada pengetahuan yang telah diperolehnya karena siswa tidak mengerti apa makna dan manfaat pengetahuan tersebut bagi kehidupannya.

Guna mendukung hasil pengamatan di atas, penulis melakukan wawancara dengan guru kelas atas (kelas 4-6). Berdasarkan hasil wawancara diketahui bahwa, dalam proses pembelajaran keliling bangun datar di kelas 4, guru seringkali harus mengajarkan materi keliling bangun datar yang seharusnya dipelajari siswa di kelas 3 . Menurut pendapat guru kelas atas tersebut, banyak siswa lupa tentang materi keliling bangun datar yang dipelajari sebelumnya sehingga guru kelas atas harus mengajarkannya kembali.

Berdasarkan kondisi yang terjadi di SD Muhammadiyah 9 Malang diperlukan suatu pembelajaran yang mampu memahamkan siswa terhadap materi keliling bangun datar, mampu meningkatkan aktivitas belajar siswa serta mampu meningkatkan kerjasama dan interaksi antar siswa. Untuk mewujudkan pembelajaran seperti yang dimaksud tersebut, maka guru perlu melaksanakan pembelajaran yang dapat meningkatkan aktivitas belajar siswa, meningkatkan kerjasama dan interaksi antar siswa melalui pembelajaran dengan setting kooperatif. Oleh karena itu, dilakukan penelitian yang berjudul "Pembelajaran Keliling Bangun Datar Menurut Standar National Council Of Teachers Of Mathematics (NCTM) dengan Setting Kooperatif Pada Siswa Kelas 3 SD Muhammadiyah 9 Malang".

\section{METODE PENELITIAN}

Dalam penelitian ini digunakan pendekatan kualitatif. Digunakan pendekatan kualitatif karena dalam penelitian ini me- 
nggunakan sumber data langsung berupa data aktivitas guru dan siswa kelas III SD Muhammadiyah 9 Malang selama proses pembelajaran berlangsung dan hasil wawancara dengan siswa. Peneliti terlibat langsung dalam proses penelitian dari awal sampai berakhirnya penelitian. Keterlibatan yang dimaksud mulai dari menyusun perangkat pembelajaran sampai pada pelaporan. Desain penelitian dapat ditinjau dan disempurnakan selama penelitian berlangsung disesuaikan dengan kenyataan dilapangan. Analisis data yang dilakukan dalam penelitian ini adalah analisis data kualitatif dan kuantitatif. Data ini dianalisis dengan langkah-langkah sebagai berikut: (1) mereduksi data, (2) menyajikan data, dan (3) meyimpulkan data.

Jenis penelitian yang digunakan adalah penelitian tindakan kelas (PTK). Dipilihnya jenis penelitian tindakan kelas dalam penelitian ini adalah karena tujuan penelitian ini sesuai dengan karakteristik PTK, yaitu ingin memperbaiki kualitas proses pembelajaran keliling bangun datar menurut standar NCTM dengan setting kooperatif. Penelitian ini berangkat dari permasalahan yang terjadi pada pembelajaran keliling bangun datar, dalam melaksanakan penelitian peneliti berkolaborasi dengan guru kelas baik pada saat pelaksanaan tindakan maupun melakukan refleksi setiap akhir tindakan. PTK sangat memperhatikan proses pembelajaran disamping hasil belajarnya, hal ini sesuai dengan proses penelitian dengan pendekatan kualitatif yang akan dilaksanakan.

Model penelitian tindakan kelas yang digunakan adalah model Kemmis dan Mc. Taggart. Penelitian dilaksanakan dalam empat tahap penelitian, yaitu: perencanaan tindakan, pelaksanaan tindakan, observasi tindakan dan refleksi yang berlangsung dalam siklus atau kegiatan berulang. Siklus berikutnya dilakukan apabila siklus yang baru dilaksanakan dianggap tidak berhasil sesuai kriteria keberhasilan yang ditetap- kan. Perencanaan siklus berikutnya memperhatikan hasil refleksi siklus sebelumnya.

Prosedur pengumpulan data dalam penelitian ini berupa validasi perangkat penelitian, pengamatan (observasi) aktivitas siswa dan aktivitas guru, wawancara, dan tes hasil belajar siswa. Perangkat penelitian yang digunakan adalah lembar validasi, lembar observasi, format wawancara, instrumen tes, rencana pembelajaran, dan lembar kerja siswa.

\section{HASIL PENELITIAN}

Data penelitian menunjukkan bahwa: dari hasil observasi pembelajaran pada siklus I dan II sudah terlaksana sesuai rencana pembelajaran. Hal ini dapat dilihat bahwa untuk pertemuan pertama rata-rata proses pembelajaran yang diketahui melalui analisis aktivitas guru dan siswa pada siklus I sebesar $94.55 \%$ dengan kategori sangat baik dan pada siklus II sebesar $98.87 \%$ dengan kategori sangat baik. Pada pembelajaran siklus II telah terlaksana dengan baik dan memenuhi kriteria keberhasilan yang ditetapkan pada penelitian ini.

Dari pembelajaran itu pula diketahui rata-rata nilai siswa mengalami peningkatan, pada rata-rata nilai tes hasil belajar siklus I sebesar $71.72 \%$ dengan kategori baik, dan kemudian rata-rata nilai pada tes akhir siklus II mengalami peningkatan menjadi $85.689 \%$ dengan kategori sangat baik, sedangkan pada nilai tes akhir siklus I dan II dapat diketahui bahwa ketuntasan belajar mengalami peningkatan, sebanyak $72,41 \%$ siswa telah mencapai skor $\geq 65$ dengan kategori baik pada siklus I dan meningkat menjadi $96.55 \%$ dengan kategori sangat baik pada siklus II, hal ini melebihi kriteria keberhasilan yaitu $80 \%$. Selain itu, rata-rata nilai proses pembelajaran mengalami peningkatan, pada siklus I sebesar $94.55 \%$ dengan kategori sangat baik meningkat pada siklus II menjadi $98.87 \%$ dengan kategori sangat baik. Hal ini mengindikasikan bah- 
wa pembelajaran menurut standar NCTM dengan setting kooperatif memungkinkan untuk dijadikan sebagai salah satu alternatif model pembelajaran yang dapat membantu siswa memahami materi.

\section{PEMBAHASAN}

Materi pembelajaran pada penelitian ini adalah keliling bangun datar, dengan fokus pembelajaran pada siklus 1 yaitu untuk meningkatkan pemahaman siswa terhadap konsep keliling bangun datar, sedangkan fokus pembelajaran pada siklus 2 yaitu mengacu pada siklus I, akan tetapi lebih ditekan pada kemahiran prosedural dan algoritma melalui soal cerita.

Pada fokus pembelajaran pada siklus 1, siswa diberi tugas melalui LKS 1 yang terdiri dari kegiatan 1 dan 2. Sedangkan pada fokus pembelajaran pada siklus 2, peneliti memberikan tugas melalui LKS 2. Pemberian tugas melalui LKS 1 dan 2 bertujuan agar siswa memahami materi yang dipelajari. Dalam menyelesaikan LKS ini, siswa juga menggunakan benda-benda berbentuk persegi maupun persegi panjang yang ada di sekitar kelas.

Pada pelaksanaan proses pembelajaran di atas ditemukan bahwa pada umumnya pemahaman siswa terhadap materi sangat baik. Hal ini pada dasarnya bergantung pada desain pembelajaran yang diterapkan. Desain pembelajaran di atas, dirancang berdasarkan teori konstruktivisme.

Temuan penelitian selanjutnya adalah dalam belajar, apabila siswa mendapatkan kesulitan mereka sangat terbantu dengan adanya bantuan dari anggota kelompok lain dan adanya wacana yang diberikan oleh guru serta wacana yang didapatkan dari diskusi kelas. Berdasarkan hasil catatan lapangan diketahui siswa dengan tingkat kemampuan tinggi memberikan bantuan kepada anggota kelompok dengan kemampuan lebih rendah. Hal ini sesuai dengan pendapat Slavin (1995:42) bahwa tanggung ja- wab individual akan membangkitkan kerja sama siswa terutama antar siswa yang berkemampuan tinggi dengan siswa yang berkemampuan rendah.

Temuan penelitian selanjutnya yaitu siswa sangat antusias dan aktif dalam belajar keliling bangun datar dengan memanfaatkan benda-benda di sekitar kelas untuk menyelesaikan soal. Keantusiasan dan keaktivan tersebut terjadi karena disebabkan oleh berbagai faktor. Salah satunya berdasarkan hasil wawancara, diketahui siswa sangat antusias dan aktif karena pembelajaran dilakukan dengan bermain. Istilah bermain, merujuk pada anggapan siswa yang menyatakan bahwa dengan memanfaatkan bendabenda di sekitar kelas, siswa diajak untuk bermain.

Temuan penelitian selanjutnya adalah adanya perbedaan pendapat dalam kelompok, bisa mendorong terjadinya diskusi antar siswa. Dalam proses pembelajarannya, para siswa berdiskusi tentang materi keliling bangun datar. Pada saat diskusi terjadi proses saling memahami ide yang dimiliki masing-masing anggota setiap kelompok dengan ide yang akan dipelajari.

Temuan penelitian selanjutnya adalah siswa mampu menemukan konsep keliling bangun datar melalui kegiatan mengukur benda-benda di sekitar kelas, kegiatan menentukan panjang maupun lebar sisinya jika diketahui kelilingnya, serta ditunjukkan pula dari kemampuan siswa dalam menyelesaikan soal cerita (tugas). Selain itu pula didukung adanya wacana, lingkungan dan analisis yang dilakukan oleh guru. Berdasarkan proses pembelajaran yang telah dilakukan, tampak empat komponen dari NCTM telah dilakukan.

Selanjutnya, ditemukan pula bahwa pada kegiatan I LKS I yang bertujuan untuk menemukan rumus keliling persegi dan persegi panjang, banyak membutuhkan waktu sehingga kegiatan pembelajaran cenderung molor dari yang direncanakan. Hal ini disebabkan karena siswanya yang aktif melaku- 
kan kegiatan menemukan dan guru lebih banyak sebagai fasilitator dan motivator bagi siswa sedangkan.

Dalam penelitian ini ditemukan pula pada soal cerita, siswa yang tidak memahami redaksi pertanyaan maka akan mengalami kesulitan dalam menyelesaikan soal. Saat menyelesaikan soal yang bersifat $o$ pen-ended tampak antusiasme siswa menurun. Upaya yang dilakukan guru pada tahap ini adalah menciptakan wacana dan lngkungan yang mendukung pada siswa. Selain itu, pada soal c ini ditemukan pula bahwa siswa belum terbiasa dengan soal openended. Di sisi lain, soal yang berbentuk $o$ pen-ended ini mampu mengkonstruksi pemahaman siswa dalam memahami soal. Hal ini dapat dipahami, karena pada soal-soal yang open-ended tersebut siswa diharuskan mampu melihat arti (makna) yang tersembunyi pada pertanyaan terbuka tersebut.

Pada akhirnya untuk mengatasi temuan terakhir dalam penelitian ini yaitu pada umumnya siswa yang berkemampuan rendah maupun siswa yang bersikap acuh tak acuh semakin termotivasi, jika dalam belajar terdapat hadiah. Guru harus melakukan upaya-upaya yang mampu meningkatkan kemampuan siswa. Berdasarkan hasil pengamatan oleh pengamat I menyatakan bahwa sikap cuek, acuh tak acuh tersebut karena terjadi karena kurangnya perhatian dan penghargaan bagi siswa yang berkemapuan kurang.

\section{KESIMPULAN}

Desain pembelajaran keliling bangun datar menurut standar National Council Of Teachers Of Mathematics (NCTM) yang dapat membangun pemahaman siswa pada materi keliling persegi dan persegi panjang dilakukan melalui tiga tahap, yaitu tahap awal, tahap inti, dan tahap akhir. Pelaksanaan kegiatan pembelajaran sudah sesuai dengan langkah-langkah pembelajaran tersebut di atas sudah terselenggara dengan baik. Hal ini ditandai oleh rata-rata proses pembelajaran yang diketahui melalui analisis aktivitas guru dan siswa pada siklus I sebesar $94.55 \%$ dengan kategori sangat baik dan pada siklus II sebesar $98.87 \%$ dengan kategori sangat baik. Pada hasil tes akhir menunjukkan bahwa rata-rata nilai tes akhir siklus I sebesar 71.72, dan kemudian hasil tes akhir siklus II rata-rata nilai tes akhir mengalami peningkatan menjadi 85.69.

Sedangkan pada ketuntasan belajar dari siklus I ke siklus II mengalami peningkatan. Sebanyak $72,41 \%$ siswa telah mencapai skor $\geq 65$ pada siklus I dan meningkat menjadi $96.55 \%$ pada siklus II, hal ini melebihi kriteria keberhasilan yaitu $85 \%$. Hasil cek pemahaman yang dilakukan dengan cara wawancara kepada siswa diketahui bahwa siswa mampu menemukan konsep keliling bangun datar.

\section{SARAN}

Beberapa saran yang dapat disampaikan berdasarkan hasil penelitian ini adalah hendaknya mengatur waktu dengan efektif dan memberikan bimbingan kepada siswa secara efektif sehingga kreatifitas siswa tetap ada.

\section{DAFTAR PUSTAKA}

Arikunto, S. 2009. Penelitian Tindakan Kelas. Jakarta: Bumi Aksara.

Depdikbud. 1999. Penelitian Tindakan. Jakarta: Direktorat Jenderal Pendidikan Dasar dan Menengah, Direktorat Pendidikan Menengah.

Depdiknas, 2005. Pedoman Penulisan Buku Pelajaran Matematika. Jakarta: Depdiknas.

Depdiknas, 2006. Kurikulum Tingkat Satuan Pendidikan (KTSP) Mata Pelajaran Matematika untuk SD/MI. Jakarta: Depdiknas 
Hudojo, Herman. 2005. Kapita Selekta Pembelajaran Matematika. Malang: Universitas Negeri Malang (UM Press)

Hudojo, Herman, dkk. 2006. Koleksi Materi Kapita Selekta Pembelajaran Matematika. Malang: Universitas Negeri Malang

Krulik, S., Rudnick, J., \& Milou, E. 2003. Teaching Mathematics in Middle SchooI. Boiston:Allyn and Bacon

Merrilyn, Goos. 2004, Learning Mathematics In a Classroom Community of Inquiry, New York, JRME.

Mulyasa, 2003. Kurikulum Berbasis Kompetensi. Bandung: PT Rosdakarya

NCTM, 1991. Professional Standard for Teaching Mathematics. Reston, virginia: The National Council of Teachers of Mathematics, Inc.
NCTM, 2000. Principles and Standards for School Mathematics. Reston, Virginia : The National Council of Teachers of Mathematics, Inc

NCTM, 2003. Mathematics Assessment: A Practical Hand Book for Grade 3 5. Reston,Virginia: The National Council of Teachers of Mathematics, Inc.New York:Cassel

Slavin. Robert. 1994. Educational Psychology: Theory and Practice. Fourth Edition. Massachusetts: Allyn and Baccon Publishers.

Van de Walle, J.A.. 1990. Elementary School Mathematics: Teaching Developmentally. New York: Longman.

Wiriaatmadja, R. 2007. Metode Penelitian Tindakan Kelas. Bandung: PT. Remaja Rosdakarya. 